\title{
Editorial \\ Child migrants at the border
}

Latino Studies (2014) 12, 329-331. doi:10.1057/lst.2014.52

By now you have probably seen the disturbing photos of dozens of young children sleeping on concrete floors in US Customs and Border Protection holding cells, clutching paper-thin silver thermal blankets to keep themselves warm. The media is finally focusing attention on the ongoing tragedy of unaccompanied migrant children crossing the border. As a report by the Migration Policy Institute points out, this disturbing phenomenon has always been part of the global migration picture (www.migrationpolicy.org/article/unaccompanied-immigrant-childrengrowing-phenomenon-few-easy-solutions). Sonia Nazario brought readers' attention to this issue in her 2002 Pulitzer Prize-winning story about Enrique, a 16-year-old Honduran boy who travels thousands of miles and encounters horrific dangers as he evades police, smugglers, bandits and other predators in his quest to reunite with his mother in North Carolina (www.pulitzer.org/ archives/6694).

While this is not a new story, the number of such youth traveling alone to the United States has risen dramatically in recent years. Before 2012, the Border Patrol apprehended approximately 6000 to 8000 unaccompanied children annually. This year, that number is expected to reach 74,000, and then rise to an estimated 140,000 children in 2015. About 75 per cent of the children come from Central America, particularly Honduras, El Salvador, and Guatemala, and most of the others are from Mexico (cgrs.uchastings.edu/our-work/treacherousjourney). After traveling many miles from Central America, they must make their way more than a thousand miles through Mexico often riding on top of freight trains branded as "la bestia." These children, some as young as 8, endure unthinkable violence such as beatings, rape and psychological trauma as they travel on their own to the United States.

While some argue that the reason for this increase is the belief promoted by coyotes and the Latin American media that once they get here, women and children will be granted "permisos" to stay, it is clear that dire circumstances across Central America that include alarming societal violence, drug wars, gang activity and related desperate conditions are precipitating this unprecedented massive exodus of children. Escalating violence at home and the fact that many have a parent in the United States compels children to risk their lives on this perilous journey. 
A recent study (2013) conducted by the United Nations High Commissioner for Refugees titled, "Children on the Run: Unaccompanied Children Leaving Central America and Mexico and the Need for International Protection" (unhcrwashington .org/children) maintains that 58 per cent of the 404 migrant children interviewed were escaping precarious situations and high levels of societal violence. They reported witnessing and experiencing multiple acts of violence, and being threatened by gangs, drug cartels and human smugglers. Children also reported other lifethreatening situations such as grinding poverty and abandonment, as well as the urgent desire to reunite with a parent in the United States.

Current policy dictates that children from border countries (Mexico and Canada) are immediately repatriated when apprehended, while the Office of Refugee Resettlement (ORR) is responsible for sheltering migrants coming from other areas. A 2008 law requires that unaccompanied children detained at the border, must be turned over to family members or to the Department of Health and Human Services (within 72 hours) while they wait for removal proceedings. By 2013, an overwhelmed ORR was running 80 shelters that temporarily housed 25,000 unaccompanied children. In June 2014, President Obama requested US\$3.7 billion from Congress to respond to this "surge" of child migrants. He tasked the Federal Emergency Management Agency with putting together a multi-agency response to the crisis. He also called for new policies that would dispense with the current law and allow the federal government to fast-track the return of these children to Central America; they would thereby lose their right to appear before a judge in immigration court.

As the UN report makes clear, given the level of violence and trauma that these children endure, many would probably be eligible for some kind of legal status including asylum, special immigrant juvenile status (for children who have suffered abandonment or abuse) or visas for trafficking victims. Advocates are calling for a system that respects the refugee status of children and ensures that they can access competent legal representation and have a fair chance to make their case for asylum.

It is undeniable that this so-called surge is the latest enactment of what Juan Gonzalez terms "the harvest of empire." The United States has an extensive history of repeated military interventions, heavy-handed neoliberal policies and inequitable free trade deals that have long enriched US corporations and the Central American elite, while increasing poverty for most people. A recent example of this misguided approach concerns US remilitarization of the region in support of its war on drugs; the United States is providing material and financial support to the Central American governments, police and the military that many see as corrupt and deeply implicated in perpetuating violence (www .cepr.net/index.php/op-eds- $\&$-columns/op-eds- $\&$-columns/the-us-re-militarizationof-central-america-and-mexico).

While humanitarian aid and legal representation should definitely be afforded to these children, it is clear that such band-aid measures will do nothing to change 
the underlying causes of this massive displacement. A long-term response to the escalating crisis must focus on reorienting US policy so that instead of continuing its historic and ongoing practice of plundering Central America through military interventions and trade deals that further impoverish farmers and workers, the US collaborates with other local states to foster sustainable economic development and restore public safety across Central America. Rebuilding economies and creating jobs that pay a living wage will be the only approach that might prevent adults and children from fleeing their countries in desperation.

Lourdes Torres

DePaul University, Chicago, IL. 